\title{
Photosynthetic pigments and carbohydrates in young Brazil nut (Bertholletia excelsa H.B.K.) plants exposed to moderate and severe water deficiency
}

Paula Francyneth Nascimento Silva ${ }^{1}$, Carla Leticia Figueredo de Carvalho Souza ${ }^{1}$, Jose Rodrigo Mendes e Chagas ${ }^{1}$, Gabriel Mascarenhas Maciel $^{2}$, Douglas José Marques ${ }^{3}$, Allan Klynger da Silva Lobato $^{1 *}$, Milton Hélio Lima da Silva ${ }^{4}$, Tiago Rodrigues Ferreira ${ }^{1}$, Maria Antonia Machado Barbosa $^{1}$, Rita de Oliveira Braga ${ }^{1}$, Thalison Bruno Campos Correa ${ }^{1}$, Gustavo Antonio Ruffeil Alves $^{1}$, Denes de Souza Barros ${ }^{1}$ and João Ricado Sena ${ }^{5}$

\author{
${ }^{1}$ Núcleo de Pesquisa Vegetal Básica e Aplicada, Universidade Federal Rural da Amazônia. \\ Paragominas, Pará, Brazil \\ ${ }^{2}$ Instituto de Ciências Agrárias, Universidade Federal de Uberlândia, Monte Carmelo, Brazil \\ ${ }^{3}$ Setor de Olericultura e Experimentação, Universidade José do Rosário Vellano (UNIFENAS), \\ Alfenas, Brazil \\ ${ }^{4}$ Coordenação de Botânica, Museu Paraense Emílio Goeldi, Belém, Pará, Brazil \\ ${ }^{5}$ Secretaria de Estado de Meio Ambiente, Belém, Pará, Brazil
}

*Corresponding author:allanllobato@yahoo.com.br

\begin{abstract}
This study aimed to evaluate the photosynthetic pigments and carbon compounds in young Bertholletia excelsa H.B.K. plants (18-month-old) subjected to 6 and 12 consecutive days without irrigation, to simulate moderate and severe water deficiency. This study will also answer the contribution of the carbohydrates related to osmotic adjustment. The experimental design was a factorial entirely randomised with two water conditions (water deficit and control) and two evaluation times (6 and 12 days), resulting in a total of four measurements. In this study, we measured chlorophyll $a$, chlorophyll $b$, total chlorophyll and carotenoids, as well as total soluble carbohydrates, sucrose, starch and reducing carbohydrates. The water restriction induced decreases in all evaluated pigments. The more intense $(45 \%)$ reduction was found in carotenoids after 12 days of water deficiency. Furthermore, decreases in total soluble carbohydrates and reducing carbohydrates were also observed. In contrast, increases were observed in sucrose and starch levels. The results suggest that water deficiency promotes negative alterations in photosynthetic pigments, while carbon compounds present insufficient responses, aiming to the osmotic adjustment in young $B$. excelsa plants exposed to water deficit.
\end{abstract}

Keywords: Bertholletia excelsa; carbohydrates; sucrose; chlorophyll; carotenoids; drought; abiotic stress.

Abbreviations: C_chloroform, CAR_carotenoids, CHL $a$ _chlorophyll $a$, CHL $b$ _chlorophyll $b$, DM_dry matter, FM_fresh matter, $\mathrm{HClO}_{4}$ _perchloric acid, LRWC_leaf relative water content, M_methanol, ROS_reactive oxygen species, TM_turgid matter, W_water.

Introduction

The Bertholletia excelsa H.B.K. is a large tree, which is one of the most important tree species in Amazon forest. It can be used as food. It also has some favourable characteristics linked to production in environment of forest, such as higher growth rate (Tonini et al., 2008; Costa et al., 2009). The occurrence of this tree is predominant in the North, also occurring in the Western of the Brazil and other Amazon countries, such as Venezuela, Colombia, Peru, Bolivia and Guyana (Tonini, 2011). The fruit can weigh of 500 to 1500 $\mathrm{g}$, and the nut seeds can be utilized as food, being a source of vegetal proteins, besides greater nutritive value. Additionally, study conducted by Chunhieng et al. (2004) described that the high selenium content of the Brazil nut makes this seed a healthy food qualified as an antiradical protector.

The chlorophylls $a$ and $b$ have greater occurrence in chloroplasts (Candan, 2003), with large interference in photosynthetic apparatus, because they are responsible for the conversion of radiation/energy under form of ATP and NADPH (Lichtenthaler, 2009). This is directly related to the photosynthetic efficiency in higher plants. In addition, these structures present a characteristics instability, dependence of nutritional supply, sensitive to light, and denaturation under high heat (Schoefs, 2002). The drought stress normally triggers significant decrease in photosynthetic pigments (Lobato et al., 2009a; Oliveira Neto et al., 2009).

The carbon metabolism is responsible for the regulation of compounds, such as total carbohydrates, sucrose, and starch, besides enzymes as sucrose synthase and invertase (Lobato et al., 2009b). Modifications in this metabolism frequently occasioned accumulation of carbon forms in leaf, producing minor translocation of carbon skeletons from source in direction to drains (Lobato et al., 2008). Studies conducted by Chaves Filho and Stacciarini-Seraphin (2001) on 
Solanum lycocarpum demonstrated decreases in total soluble carbohydrates and reducing carbohydrates from leaves in response to water deficit. Albuquerque et al. (2013) showed reduction in total soluble carbohydrates in young Khaya ivorensis plants. Therefore, this study aimed to evaluate photosynthetic pigments and carbon compounds in young Bertholletia excelsa plants exposed to water deficiency, as well as it will answer the contribution of the carbohydrates related to osmotic adjustment in this specie.

\section{Results}

\section{Reduction in leaf water content}

The water deficit promoted significant reduction in relation to leaf relative water content in both evaluated points (Fig. 1), being showed decrease of 22.6 and $43.3 \%$ during 6 and 12 days, respectively.

\section{Modifications in pigment contents}

The water restriction induced significant decrease in chlorophyll $a$ only after $12^{\text {th }}$ day of tress (Fig. 2A). A reduction of 8.6 and $19.8 \%$ was verified after 6 and 12 days, respectively. In relation to chlorophyll $b$, the water deficiency caused significant decrease in both evaluated points (Fig. 2B). During 6 and 12 days decreases of 23.4 and $23.3 \%$ were obtained, respectively. For chlorophyll total, the drought occasioned significant reduction to two evaluated points (Fig 2C), being showed decreases of 16.8 and $21.5 \%$ in 6 and 12 days, respectively. The water limitation induced significant decrease in carotenoids (Fig. 2D) only after 12 days. The decrease showed in 6 and 12 days were 17.3 and $45.8 \%$, respectively.

\section{Changes in carbon skeletons induced by water deficit}

The water deficit caused non-significant decrease in the total soluble carbohydrates, in evaluated days (Fig. 3A), showing 5.0 and $10.4 \%$ decreases in 6 and 12 days, respectively. The water limitation induced significant increase in sucrose only after 12 days (Fig. 3B), with 5.1 and $39.7 \%$ increases during 6 and $12^{\text {th }}$ day, respectively. The water deficit also significantly increased the starch content at both evaluated days (Fig. 3C), resulting in increases of 30.2 and $38 \%$ in 6 and 12 days, respectively. The water deficiency significantly decreased the carbohydrate contents at two studded points (Fig. 3D), with 30.3 and 93.5\% reductions, at 6 and 12 days of stress, respectively.

\section{Discussion}

The decrease in leaf relative water content can be attributed to combination of higher evaporation rate and lower water availability in substrate. Plants exposed to water restriction normally loss water to atmosphere by the transpiration (Silva et al., 2012) in minor proportion, when compared with the water assimilation via root system (Freitas et al., 2007). Similar results linked to decrease of this parameter were reported by Fioreze et al. (2011) on Glycine max plants under water deficit.

The chlorophyll $a$ was reduced due to water deficiency, and this effect can be related with action of reactive oxygen species (ROS). Normally, the formation and consequently accumulation of ROS induce gradual damage in chlorophyll molecules (Carvalho et al., 2003). Similar results reported by Ullah et al. (2003), whose verified that the reduction in water availability, growth and oil in Brassica napus occur due to a decrease in chlorophyll $a$. The water deficit also caused reduction in chlorophyll $b$ and chloroplast degradation. In agreement with Marcondes and Garcia (2009), the decrease in chlorophylls is a consequence of breakdown in thylakoid membranes, liberating the content of chloroplasts, such as chlorophyll $b$, into the cytosol. These results are corroborated by Sircelj et al. (2005) who studied two Malus domestica plants subjected to water deficiency. The levels of total chlorophyll were reduced probably by the degradation of the carotenoids that play important role in photo-protection process of chlorophylls (Cardoso, 1997), and consequently will minimize the chloroplast degradation. Similar results are showed by Bastos et al. (2011) investigating cowpea genotypes subjected to water deficit. The water restriction causes reduction of carotenoids. This fact might probably be explained by limitations in biosynthesis pathway of the carotenoids, mediated by lycopene. The lutein and $\beta$ carotene normally are the carotenoids found in large amount ino thylakoid membranes (Roca and Mínguez-Mosquera, 2003), synthesising both carotenoids depending to lycopene (Ruiz-Sola and Rodríguez-Concepción, 2012). The carotenoids are molecules that are accumulated in chloroplasts, and linked to photorespiration, as well as protein stabilisation in photosystem (Rissler and Pogson, 2001; Simkin et al., 2008). Similar results were reported by Loggini et al. (1999), evaluating Triticum aestivum cultivars.

The total soluble carbohydrates were reduced in plants exposed to water deficiency. This effect is associated paradoxically to non-osmotic adjustment of Bertholletia excelsa plants through accumulation of carbon skeletons. Additionally, the decrease of total carbohydrates after 12 days of drought stress was occurred due to these organic compounds, working as energy (Lobato et al., 2008). They supposed to be used during carbon reallocation by the root system under conditions of severe water deficit (Pimentel, 2004). Similar results were obtained by Melo et al. (2007) studying Setaria anceps plants subjected to water limitation. The sucrose increase is probably due to lower invertase activity. This enzyme is responsible for sucrose degradation (Ren and Zhang, 2013), and it suffers negative interference with the water availability in plants (Tian-Hong and ShaoHua, 2007; Geigenberger et al., 1997). The sucrose hydrolysis is fundamental in carbon metabolism. The glucose and fructose are catalysed from sucrose by reaction of invertase and can be utilized as source of energy (Martinez et al., 2007; Leite et al., 2011). Similar results were obtained by Leite et al. (2011), investigating Saccharum officinarum plants.

The increase in starch concentration after water deficit can be explained by the lower $\alpha$-amylase activity, in which it is responsible by the starch hydrolysis. According to Amaral (2007), several enzymes, mostly hydrolysis-related, are involved in the mobilisation of starch. The $\alpha$-amylase carries out the division of starch molecules through glycosidic hydrolysis of glycosidic connections, producing carbohydrates such as maltose and glucose (Walter and Emanuelli, 2005). Lee et al. (2008) revealed that the water deficit negatively affects the photosynthesis, with negative consequence on starch production.

The decrease in concentration of carbohydrates is linked to combination of two effects. Primarily influence by the increase in sucrose levels, and second lack of contribution of total carbohydrates in osmotic adjustment in this species. Contrasting results were reported by Lobato et al. (2008) working with Glycine max plants. 


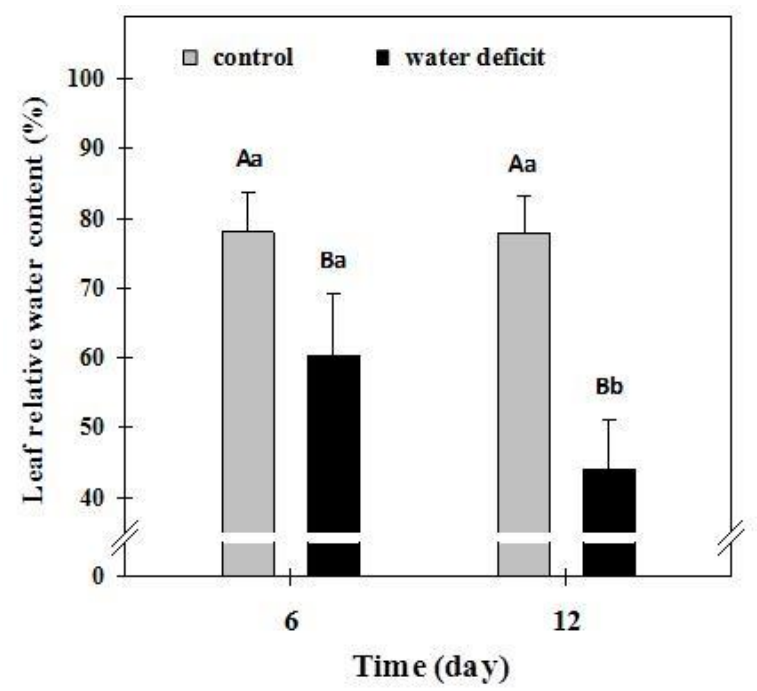

Fig 1. Leaf relative water content in young Bertholletia excelsa plants subjected to water deficit. Averages followed by the same uppercase letters within each time (6 or 12 days) and lowercase letters within water conditions (control or water deficit) do not differ among themselves at the Skott-Knott test at 5\% probability. The bars represent the mean standard errors.

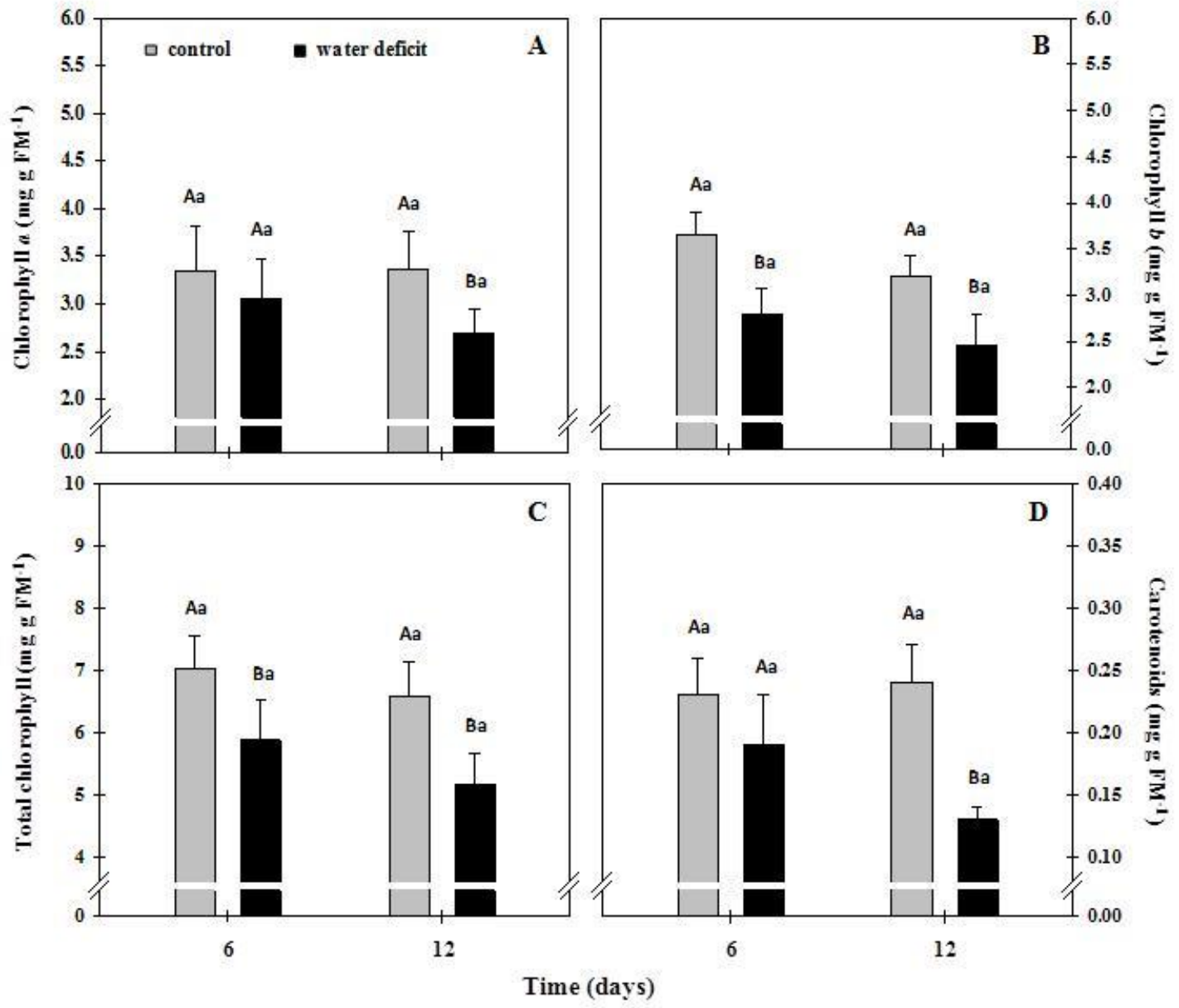

Fig 2. Chlorophyll $a$ (A), chlorophyll $b$ (B), total chlorophyll (C), and carotenoids (D) in young Bertholletia excelsa plants subjected to water deficit. Averages followed by the same uppercase letters within each time (6 or 12 days) and lowercase letters within water conditions (control or water deficit) do not differ among themselves at the Skott-Knott test at 5\% probability. The bars represent the mean standard errors. 


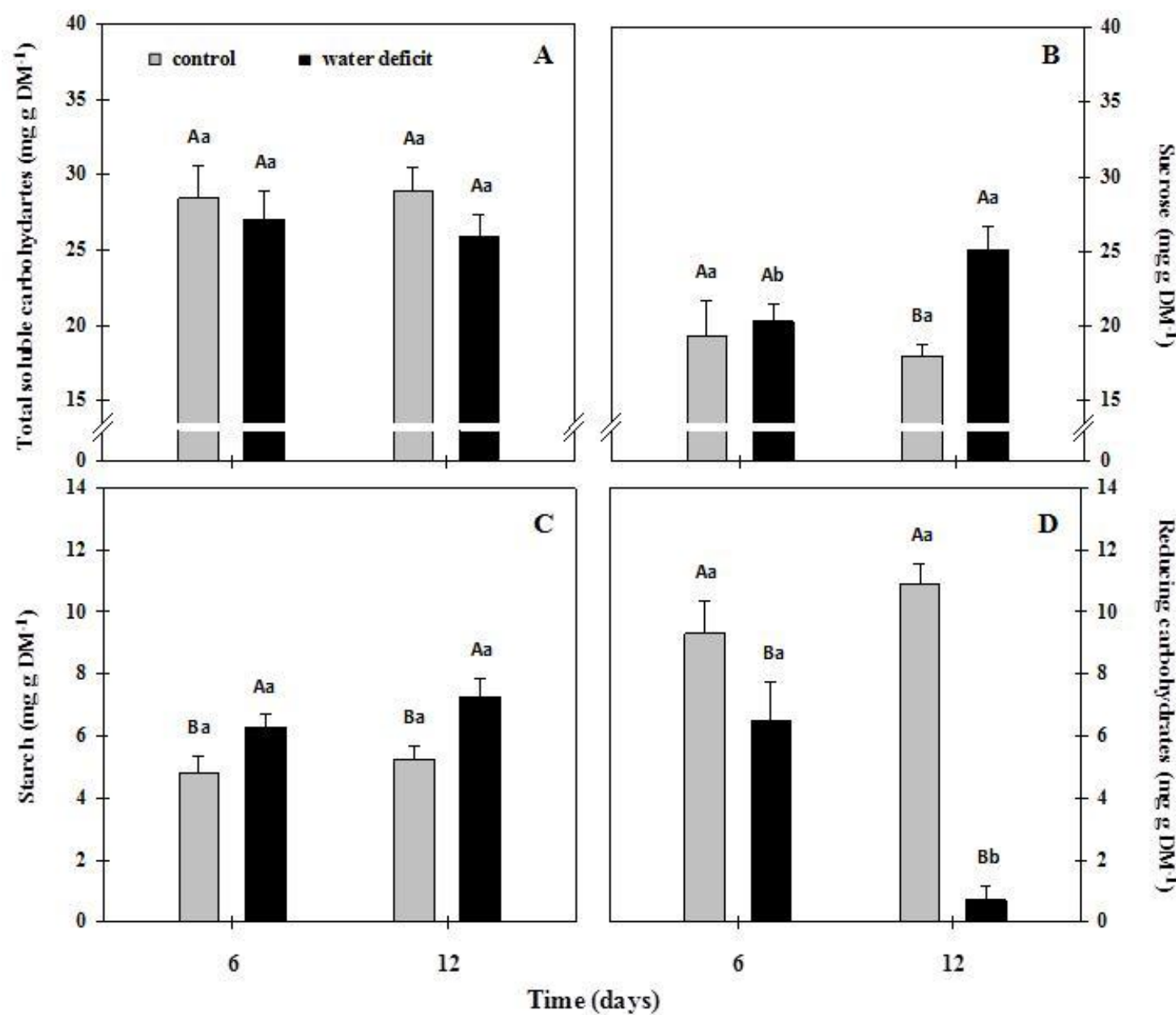

Fig 3. Total soluble carbohydrates (A), sucrose (B), starch (C), and reducing carbohydrates (D) in young Bertholletia excelsa plants subjected to water deficit. Averages followed by the same uppercase letters within each time (6 or 12 days) and lowercase letters within water conditions (control or water deficit) do not differ among themselves at the Skott-Knott test at 5\% probability. The bars represent the mean standard errors.

\section{Materials and Methods}

\section{Localisation and growth conditions}

The experiment was performed in Campus of Paragominas of the Universidade Federal Rural da Amazônia, Paragominas city, Brazil ( $2^{\circ} 55^{\prime} \mathrm{S}$ and $\left.47^{\circ} 34^{\prime} \mathrm{W}\right)$. This study was conducted in greenhouse without environmental control. The minimum, maximum and median temperatures were 33 , 26 , and $22{ }^{\circ} \mathrm{C}$, respectively. The relative humidity during the experimental period oscillated between 65 and $93 \%$, and the photoperiod was set to $12 \mathrm{~h}$ of light. During measurements the photosynthetic active radiation oscillated between 451 and $1453 \mu \mathrm{mol} \mathrm{m}^{-2} \mathrm{~s}^{-1}$ (at $12 \mathrm{~h}$ ).

\section{Plant, container, and substrate}

Seeds of Bertholletia excelsa (Bonpl.) were germinated in pots with dimensions of $0.25 \times 0.20 \mathrm{~m}$ for height and diameter, respectively, presenting capacity of $8 \mathrm{~L}$, and holes for water drainage. Pots were filled with sand, and irrigation was implemented daily with $1 \mathrm{~L}$ of deionized water. After 90 days seedlings with similar aspect and size were selected. Subsequently, seedlings with 120 old-days received $0.2 \mathrm{~L}$ of
Hoagland and Arnon (1950) nutrient solution modified for this species, and this nutritional supplementation was applied at regular intervals of 30 days until $18^{\text {th }}$ month.

\section{Experimental design}

The experimental design was in factorial entirely randomised with two water conditions (water deficit and control) and two evaluation points (6 and 12 days), resulting in a total of 4 measurements. This experiment was assembled with 5 replicates for a total of 20 experimental units, with 1 plant in each unit.

\section{Water deficit application and harvest}

All the plants were grown until the $18^{\text {th }}$ month as described above. Subsequently, the plants under the water deficit treatment were submitted to 12 consecutive days without irrigation. The plants under the control treatment were watered daily with distilled water. Measurements linked to leaf relative water content were carried out to each evaluation period. Additionally, the plants were harvested, and the middle leaves of the plant were collected. After that, 
the leaves were frozen in liquid nitrogen and kept at $-20{ }^{\circ} \mathrm{C}$ for subsequent biochemical determinations.

\section{Leaf relative water content}

The leaf relative water content (LRWC) was evaluated in leaf disks of $10 \mathrm{~mm}$ diameter. For each plant 40 disks were removed and this parameter was calculated using the formula LRWC $=[(\mathrm{FM}-\mathrm{DM}) /(\mathrm{TM}-\mathrm{DM})] \times 100$, proposed by Slavick (1979), Where; FM is fresh matter, TM is turgid matter evaluated after $24 \mathrm{~h}$ and saturated in deionized water at $4{ }^{\circ} \mathrm{C}$ in the dark, and $\mathrm{DM}$ is the dry matter determined after $48 \mathrm{~h}$ in an oven with forced air circulation at $80^{\circ} \mathrm{C}$.

\section{Chlorophyll content}

The determination of the photosynthetic pigments was carried out with $25 \mathrm{mg}$ of leaf tissue. The samples were homogenized in the dark and in the presence of $2 \mathrm{~mL}$ of acetone at $80 \%$ (Nuclear). Subsequently, the homogenate was centrifuged at 5,000 $\mathrm{g}$ for 10 minutes in the temperature of $5^{\circ} \mathrm{C}$. The supernatant was removed and the chlorophyll $a$ and $b$, carotenoids and total pigments were quantified using spectrophotometer Femto (700 S), according to the methodology of Lichthenthaler (1987).

\section{Total soluble carbohydrates and starch}

For determination of total soluble carbohydrates $50 \mathrm{mg}$ of leaf powder was incubated with $5 \mathrm{~mL}$ of ultrapure water at $100^{\circ} \mathrm{C}$ for $30 \mathrm{~min}$, centrifuged at $2,000 \mathrm{~g}$ for $5 \mathrm{~min}$ at $20^{\circ} \mathrm{C}$ and the supernatant was removed. For determination of starch $50 \mathrm{mg}$ of powder was incubated with $5 \mathrm{~mL}$ of ethanol at $80^{\circ} \mathrm{C}$ for $30 \mathrm{~min}$, centrifuged at $2,000 \mathrm{~g}$ for $10 \mathrm{~min}$ at $25^{\circ} \mathrm{C}$, and the supernatant was removed. In addition, a second extraction was carried out with the same powder incubated with $5 \mathrm{~mL}$ of $30 \% \mathrm{HClO}_{4}$ at $25^{\circ} \mathrm{C}$ for $30 \mathrm{~min}$ and centrifuged in conditions previously described. The supernatants of the two extractions were mixed. The quantifications of the total soluble carbohydrates and starch were carried out at $490 \mathrm{~nm}$ using the method of Dubois et al. (1956), using glucose (Sigma Chemicals) as standard.

\section{Sucrose and reducing carbohydrates}

The determination of sucrose was carried out with $50 \mathrm{mg}$ of leaf powder incubated with $1.5 \mathrm{~mL}$ of solution MCW (methanol, chloroform and water) in the proportion of 12:5:3 $(\mathrm{v} / \mathrm{v})$ at $20^{\circ} \mathrm{C}$ by $30 \mathrm{~min}$ under agitation, centrifuged at $10,000 \mathrm{~g}$ for 10 minutes at $20^{\circ} \mathrm{C}$ and the supernatant was removed. The sucrose quantification was carried out at 620 nm, in agreement with Van Handel (1968), using sucrose (Sigma Chemicals) as standard. For determination of the reducing carbohydrates, this parameter was calculated as the difference between the total soluble carbohydrate total and sucrose (Chaves Filho and Staccirani-Seraphin, 2001).

\section{Data analysis}

The data were subjected to variance analysis and when significant differences observed between averages, they were applied to the Skott-Knott test at 5\% level of error probability (Steel et al., 2006). The mean standard errors were calculated in all evaluation points and water conditions.

\section{Conclusion}

The water restriction decreased all evaluated pigments. The more intense reduction (45\%) belonged to carotenoids after 12 days under water deficit. The carbon compounds such as total soluble carbohydrates and reducing carbohydrates were also decreased due to water deficit. However, increases in sucrose and starch levels were observed. These results suggest that water deficiency promotes negative alterations in photosynthetic pigments, while carbon compounds present insufficient responses, aiming the osmotic adjustment of young Bertholletia excelsa plants exposed to progressive water deficit.

\section{Acknowledgments}

This research financially supported by Universidade Federal Rural da Amazônia (UFRA/Brazil), Fundação de Fundação Amazônia Paraense de Amparo à Pesquisa (FAPESPA) and Conselho Nacional de Desenvolvimento Científico e Tecnológico (CNPq/Brazil) to Lobato A.K.S.

\section{References}

Albuquerque MPF, Moraes FKC, Santos RIN, Castro GLS, Ramos EMLS, Pinheiro HA (2013) Ecophysiology of seedlings of African mahogany subjected to water deficit and rehydration. Pesqui Agropecu Bras. 48:9-16.

Amaral LIV, Gaspar M, Costa PMF, Aidar MPM, Buckeridge MS (2007) New rapid and sensitive enzymatic method for extraction and quantification of starch in plant materials. Hoehnea. 34:425-431.

Bastos EA, Nascimento SP, Silva EMS, Freire Filho FR, Gomide RL (2011) Identification of cowpea genotypes for drought tolerance. Rev Ciênc Agron. 42:100-107.

Candan N, Tarhan L (2003) Relationship among chlorophyll-carotenoid content, antioxidant enzyme activities and lipid peroxidation levels by $\mathrm{Mg}^{2+}$ deficiency in the Mentha pulegium leaves. Plant Physiol Biochem. 41: 35-40.

Cardoso SL (1997) Photophysics of carotenoids and the antioxidant role of $\beta$-carotene. Quim Nova. 20:535-540.

Carvalho LM, Casali VWD, Souza MA, Cecon PR (2003) Availably of water in soil and Artemisia growth. Hortic Bras. 21:726-730.

Chaves Filho J, Staccirani-Seraphin E (2001) Change in osmotic potential and soluble carbohydrates in young plants of lobeira (Solanum lycocarpum St,-Hill) in response to water stress. Rev Bras Bot. 24:199-204.

Chunhieng T, Tritis KP, Elfakir C, Brochier J, Goli T, Montet D (2004) Study of selenium distribution in the protein fractions of the brazil nut, Bertholletia excelsa. J Agr Food Chem. 52:4318-4322.

Costa JR, Castro ABC, Wandelli EV, Coral SCT, Souza SAG (2009) Silvicultural aspects of Brazil nut (Bertholletia excelsa) in agroforestry systems in Central Amazonia. Acta Amaz. 39:843-850.

Dubois M, Gilles KA, Hamilton JK, Rebers PA, Smith F (1956) Colorimetric method for determination of sugars and related substances. Anal Chem. 28:350-356.

Fioreze SL, Pivetta LG, Fano A, Machado FR, Guimarães VF (2011) Performance of soybean genotypes under high intensity drought stress in greenhouse conditions. Ceres. 58:342-349.

Freitas JMN, Carvalho KS, Lobato AKS, Castro DS, Maia PSP, Oliveira Neto CF, Costa RCL (2007) Activities of redutase of nitrato, relative water content and total soluble 
chlorophyll in leaves of Açaizeiro (Euterpe edulis Mart.) under water deficit and flooding. Rev Bras Bioscienc. 5:924-926.

Geigenberger P, Reimholz R, Geiger M, Merlo L, Canale V, Stitt M (1997) Regulation of sucrose and starch metabolism in potato tubers in response to short-term water deficit. Planta. 201:502-518.

Hoagland DR, Arnon DI (1950) The Water Culture Method for Growing Plants without Soil. University of California Press: Berkeley, USA. 347p.

Lee BR, Jina YL, Jung WJ, Jungc D, Avicee JC, Annette M.B, Ourry A, Park CW, Kim TH (2008) Water-deficit accumulates sugars by starch degradation - not by de novo synthesis - in white clover leaves (Trifolium repens). Physiol Plantarum. 134:403-411.

Leite GHP, Crusciol CAC, Silva MA, Lima GPP (2011) Invertases enzymes activity and sucrose accumulation in sugarcane (Saccharum officinarum L.) under effect the potassium nitrate, ethephon and ethyl-trinexapac. Cienc Agrotec. 35:649-656.

Lichthenthaler HK (1987) Chlorophylls and carotenoids: Pigments of photosynthetic biomembranes. Method Enzymol. 148:350-382.

Lichtenthaler HK (2009) Biosynthesis and accumulation of isoprenoid carotenoids and chlorophylls and emission of isoprene by leaf chloroplast. Bull Georgian Natl Acad Sci. 3:81-94.

Lobato AKS, Costa RCL, Neto MAM, Oliveira Neto CF, Santos Filho BG, Alves GAR, Freitas JMN, Cruz FJR, Marochio CA, Coimbra GK (2009a) Responses of the photosynthetic pigments and carbon metabolism in Vigna unguiculata cultivars submitted to water deficit. Res J Biol Sci. 4:593-598.

Lobato AKS, Luz LM, Costa RCL, Tan DKY, Bonato CM, Silva MHL, Oliveira Neto CF, Silva LI (2009b). Relationship between chlorophyll a and total soluble carbohydrates in pepper submitted to water deficiency. J Anim Plant Sci. 2:515-526.

Lobato AKS, Oliveira Neto CF, Santos Filho BG, Costa RCL, Cruz FJR, Neves HKB, Lopes MJS (2008) Physiological and biochemical behavior in soybean (Glycine max cv. Sambaiba) plants under water deficit. Aust J Crop Sci. 2:25-32.

Loggini B, Scartazza A, Brugnoli E, Navari-Izzo F (1999) Antioxidant defense system, pigment composition, and photosynthetic efficiency in two wheat cultivars subjected to drought. Plant Physiol. 119:1091-1099.

Marcondes J, Garcia AB (2009) Cytomorphologic aspects of saline stress on rice (Oryza sativa L.) seedlings. Arq Inst Biol. 76:187-194.

Martinez JP, Lutts S, Schanck A, Bajji M, Kinet JM (2007) Is osmotic adjustment required for water stress resistance in the Mediterranean shrub Atriplex halimus L. J Plant Physiol. 161:1041-1051.

Melo HC, Castro EM, Soares AM, Melo LA, Alves JDA (2007) Anatomical and physiological alterations in Setaria anceps Stapf ex Massey and Paspalum panculatum L. under water deficit conditions. Hoehnea. 34:145-153.

Oliveira Neto CF, Lobato AKS, Gonçalves-Vidigal MC, Costa RCL, Santos Filho BG, Alves GAR, Maia WJMS,
Cruz FJR, Neves HKB, Lopes MJS (2009) Carbon compounds and chlorophyll contents in sorghum submitted to water deficit during three growth stages. J Food Agric Environ. 7:588-593.

Pimentel C (2004) The relation of the plant with water. Edur: Seropédica, BR. 190p.

Ren X, Zhang J (2013) Research progresses on the key enzymes involved in sucrose metabolism in maize. Carbohydr Res. 368:29-34.

Rissler H, Pogson BJ (2001) Antisense inhibition of the beta-carotene hydroxylase and nonphotochemical quenching in Arabidopsis. Photosynth Res. 67:127-137.

Roca M, Mínguez-Mosquera IM (2003) Carotenoid levels during the period of growth and ripening in fruits of different olive varieties (Hojiblanca, Picual and Arbequina). J Plant Physiol. 160:451-459.

Ruiz-Sola MA, Rodríguez-Concepción M (2012) Carotenoid biosynthesis in Arabidopsis: A colorful pathway. The Arabidopsis Book. 10:1-28.

Schoefs B (2002) Chlorophyll and carotenoid analysis in food products. Properties of the pigments and methods of analysis. Trends Food Sci Tech. 13: 361-371.

Silva ON, Lobato AKS, Avila FW, Costa RCL, Oliveira Neto CF, Santos Filho BG, Martins Filho AP, Lemos RP, Pinho JM, Medeiros MBCL, Cardoso MS, Andrade IP (2012) Silicon-induced increase in chlorophyll is modulated by the leaf water potential in two waterdeficient tomato cultivars. Plant Soil Env. 58:481-486.

Simkin AJ, Moreau H, Kuntz M, Pagny G, Lin C, Tanksley S, McCarthy J (2008) An investigation of carotenoid biosynthesis in Coffea canephora and Coffea arabica. J Plant Physiol. 165:1087-1106.

Sircelj H, Tausz M, Grill D, Batic F (2005) Biochemical responses in leaves of two apple tree cultivars subjected to progressing drought. J Plant Physiol. 162:1308-1318.

Slavick B (1979) Methods of Studying Plant Water Relations. Springer Verlang: New York, USA. 449p.

Steel RGD, Torrie JH, Dickey DA (2006) Principles and procedures of statistics: a biometrical approach, Academic Internet Publishers: Moorpark, USA. 666p.

Tian-Hong, Shao-Hua (2007) Leaf responses of micropropagated apple plants to water stress: changes in endogenous hormones and their influence on carbohydrate metabolism. Agr Sci China. 6:58-67.

Tonini H, Kaminski PE, Costa P (2008) Relationship of Brazil-nut seed yield to crown morphometric characteristics and competition indexes. Pesqui Agropec Bras. 43:1509-1516.

Tonini H (2011) Phenology of Brazil nut (Bertholletia excelsa Humb. \& Bonpl., Lecythidaceae) in south of Roraima State. Cerne. 17:23-131.

Ullah F, Bano A, Nosheen A (2012) Effects of plant growth regulators on growth and oil quality of canola (Brassica napus L.) under drought stress. Pak J Bot. 44:1873-1880.

Van Handel E (1968) Direct microdetermination of sucrose. Anal Biochem. 22:280-283.

Walter M, Silva LP, Emanuelli, T (2005) Starch resistant: characteristics physical chemistry, physiological proprieties and methods of quantification. Ciênc Rural. 35:974-980 